Ocean Sci. Discuss., 8, 1601-1630, 2011

www.ocean-sci-discuss.net/8/1601/2011/

doi:10.5194/osd-8-1601-2011

(C) Author(s) 2011. CC Attribution 3.0 License.

\title{
Estimating suspended sediment concentrations using a broadband ADCP in Mahshahr tidal channel
}

\section{P. Ghaffari ${ }^{1,2}$, J. Azizpour ${ }^{2}$, M. Noranian ${ }^{2}$, V. Chegini ${ }^{3}$, V. Tavakoli ${ }^{4}$, and} M. Shah-Hosseini ${ }^{5}$

${ }^{1}$ Department of Geosciences, University of Oslo, Blindern, 0315, Oslo, Norway

${ }^{2}$ Department of Physical Oceanography, Iranian National Institute for Oceanography, Iran

${ }^{3}$ Department of Marine Engineering, Iranian National Institute for Oceanography, Iran

${ }^{4}$ Department of Geology, School of Science, University of Tehran, Iran

${ }^{5}$ Centre European de Recherche et d Enseignement en Geosciences de I Environment CNRS, France

Received: 21 April 2011 - Accepted: 17 June 2011 - Published: 7 July 2011

Correspondence to: P. Ghaffari (peygham.ghaffari@geo.uio.no)

Published by Copernicus Publications on behalf of the European Geosciences Union.
Estimating SSC from ADCP backscatter

P. Ghaffari et al.

\section{Title Page}

\section{Abstract}

Introduction

Conclusions

References

Tables

Figures

14

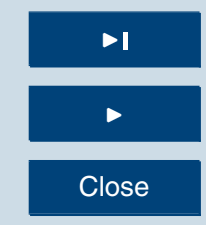

Back

\section{Full Screen / Esc}

Printer-friendly Version

Interactive Discussion 


\section{Abstract}

Data sets of Acoustic Doppler Current Profiler (ADCP) backscatter intensities (ABS) were used to evaluate suspended sediment concentrations (SSC) in the Mahshahr Channel (MC) of the Persian Gulf. Since the echo intensity is closely related to turbid-

5 ity in water, the ADCP may be a promising tool to monitor the sediment transport. The low susceptibility of the acoustic backscatter to bio-fouling and the ADCP provision of current profiles as well as sediment time series makes this monitoring method more advantageous compared with the traditional methods. Time series of ADCP backscatter intensity profiles were used for improving temporal resolution of SSC estimates.

10 Backscatter and traditional observational data were separated into two segments. The first part was utilized for calibrating the backscatter data and attributing the intensity to suspended particle concentrations and using the second part acoustic intensities were validated. Acoustic based SSC estimates are slightly underestimated in comparison with traditional water sample based SSC values, but still there is good agreement be15 tween acoustic SSC and traditional observations. Results illustrate a rather high correlation between lab based and acoustic based particles in suspension $\left(R^{2}=88 \%\right)$. Additionally measurements reveal the domination of a semidiurnal ebb asymmetric system in the MC. Tidal currents provide the main energy source for particle resuspension and transport. Maximum suspended load concentrations are evident in ebb tides, while the currents strengths are enough to refloat loads from the bed. In general spring tides show higher SSC values compared with neap tides in the study area.

\section{Introduction}

The Mahshahr Channel (MC) which is located at the north western part of the Persian Gulf (PG) is subject to intensified pressure due to the urban and industrial activities.

Determining the effects of the coastal developments on different hydrodynamical processes such as tidal patterns and sediment transport depends on understanding of the underlying physical structure, particularly estuarine circulation. Tidal forcing plays the

OSD

$8,1601-1630,2011$

\section{Estimating SSC from ADCP backscatter}

P. Ghaffari et al.

\section{Title Page}

Abstract Introduction

Conclusions References

Tables Figures

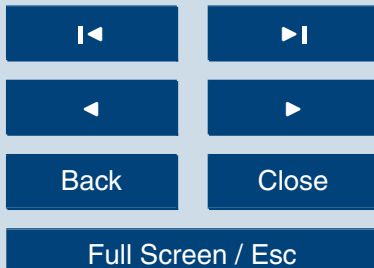

Printer-friendly Version

Interactive Discussion 
main role in the net estuarine circulation at subtropical latitudes (Murphy and ValleLevinson, 2008). Suspended sediment transport due to circulation in turbid estuaries is one of the most important natural problems. In general tidal pumping in these areas is the dominant process to establish the turbidity maxima (Dyer, 1997). Suspension, 5 transport and deposition of sediments in estuaries and bays are processes of critical significance to understanding the overall condition of these variable marine systems. In addition to biological and chemical effects on the estuarine environment because of providing habitat for benthic organisms and carrying nutrients, pollutants as well as toxic materials (Hammond et al., 1985; Webster and Lemckert, 2002), the depo10 sition of sediments in the shipping channels requires periodic dredging to maintain those channels in navigable condition. Suspended sediment concentrations (SSC) in estuaries and tidal channels are determined by the combination of hydrodynamics, physicochemical and biological processes (Chen et al., 2006).

Knowledge of flow fields in estuaries and turbid channels is compulsory to under15 stand the SSC and its transport. A wide variety of techniques have been used to measure fluid velocity and sediment transport in estuaries. The primary traditional measurement technique was periodic sampling in different layers in the water column for later analysis. The main limitation of sampling concerns the changeable character of suspended materials. Even collecting regular water samples cannot accurately define a time series of suspended material that is often highly (spatially and temporally) variable and is modified by tidal currents, water depth and wind effects (Gartner, 2004). Using ordinary current meters and taking periodic water samples may be suitable in some cases, but this method has some limitations in bays and estuaries where characters of flow fields and suspended materials are potentially fluctuating, (Gartner, 25 2004).

Utilizing optical backscatter (OBS) sensors is useful to addressing the variable nature of SSC, but the calibration of these sensors is complicated due to its dependency on the grain size (Downing, 1996). Additionally OBS sensors are not operational in the long term in highly productive estuaries owing to intense sensitivity to bio-fouling

\section{OSD}

$8,1601-1630,2011$

\section{Estimating SSC from ADCP backscatter}

P. Ghaffari et al.

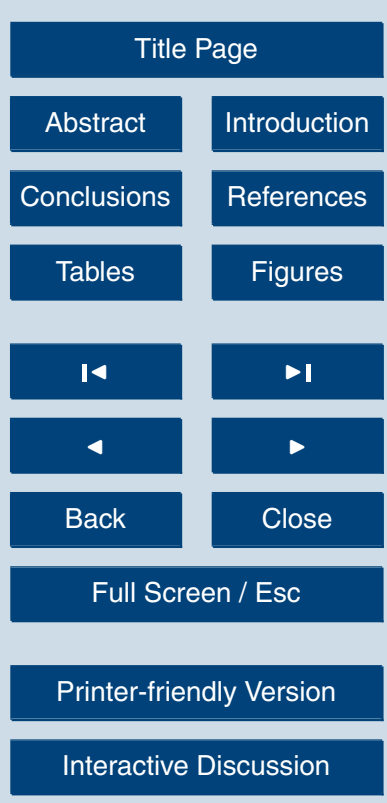


(Hamilton et al., 1998). Alternatively, acoustic sensors that are far less susceptible to effects of biological fouling have shown promise for determining reliable estimates of suspended solids (Hay and Sheng, 1992; Osborne et al., 1994; Thorne et al., 1991). Besides being less susceptible to bio-fouling, commercially available ADCPs provide 5 nonintrusive estimates of SSC profiles and time series concurrent with measurements of velocity using the same instrument.

For more than two decades Acoustic Doppler Current Profilers (ADCPs) have been in common use measuring current profiles. Efforts to quantify suspended materials from acoustic backscatter intensity measurements by those acoustic instruments used 10 to measure water velocity are one of the consequences of the widespread utilization of ADCPs (Reichel and Nachtnebel, 1994; Thevenot et al., 1992). Recently utilizing acoustic backscatter intensity of ADCPs in order to estimate suspended materials is becoming common particularly in estuaries and bay systems (Gartner, 2004; Longdill and Healy, 2007; Murphy and Valle-Levinson, 2008; Shi et al., 2006; Yuan et al., 2008). 15 The backscatter signal could be used to not only evaluate the Doppler shift but also to extract information on the scatterers (Holdaway et al., 1999). Providing non-intrusive estimates of suspended materials in parallel with current field velocities, through the water column in definite layers and being less susceptible to bio-fouling, makes this method advantageous relative to the traditional measurement techniques.

The purpose of our study is reporting results of a field campaign conducted off the Mahshahr Channel (MC), Persian Gulf, in autumn 2006, and addressing some fundamentals of the basic hydrodynamical processes controlling the suspended sediments transport in the study area. Therefore a combination of hydrodynamics and suspended sediment measurements are taken in order to investigate the flow field patterns and the possible sediment resuspension mechanisms. A description of the study area and data gathering scheme is given in Sect. 2. Section 3 deals with data methods for estimating the current field and SSC. In Sect. 4 hydrodynamics and its association with sediment concentration is presented and discussed. The paper is completed with an uncomplicated conclusion in Sect. 5.

\section{OSD}

$8,1601-1630,2011$

\section{Estimating SSC from ADCP backscatter}

P. Ghaffari et al.

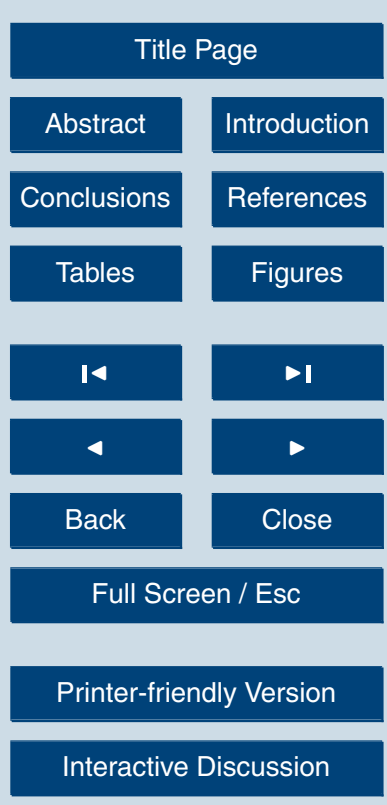




\section{Field survey}

\subsection{Study area}

The MC is a natural bay system which is located in the northwest of the PG. The geometry around the $\mathrm{MC}$ is specific and combination of several auxiliary jointed chan-

5 nels makes it unique in terms of hydrodynamics and suspended sediment concentration. The tides in the bay are rather semidiurnal with a maximum range of $3.5 \mathrm{~m}$ (http://www.irangulf.com/ports_mahshahr.htm). Suspended sediment concentrations (SSC) are quite high and the bed sediments of the bay are composed mainly of silt, however sediments toward the mouth of the bay in the PG become coarser due to 10 entrainment by tidal currents. During the present study, in-situ bottom grab sediment samples analyzed in the laboratory reveal a normal distribution of particle size with a significant abundance in the range of clay to silt (i.e., 0.5 to $50 \mu \mathrm{m}$ ). There is no significant river or other fresh water discharge in to this bay system or into its tributaries except that from Douragh channel seasonally due to Shadegan pond. As the MC is a semi-enclosed system, no apparent waves were generated according to observations and sea level records.

The Imam Port Complex (IPC) at the end of the MC, accepting very large ships at its various types of berths, is another prominent feature of the study area. Locating the port at the end of the $\mathrm{MC}$ has made it very well protected against sea waves. Although the port initially had a good potential to increasing capacities, strong tidal elevation and currents posed a serious and complex problem because of sedimentation. As in other ports in the world, the most important obstacles for developing the IPC are transportation accessibility, wharfs and disembarking. Making a new port is expensive so developing methods to increase loading capacities of ports seemingly are reasonable. Land reclamation and making new wharfs are popular to increase capacity especially for ancient ports. Of course, land reclamation can make a new sedimentation regime around the neighboring wharf which might create some hazardous effect on the port. The two most important berths of the port in the vicinity of the barge harbor are the

\section{Estimating SSC from ADCP backscatter}

P. Ghaffari et al.

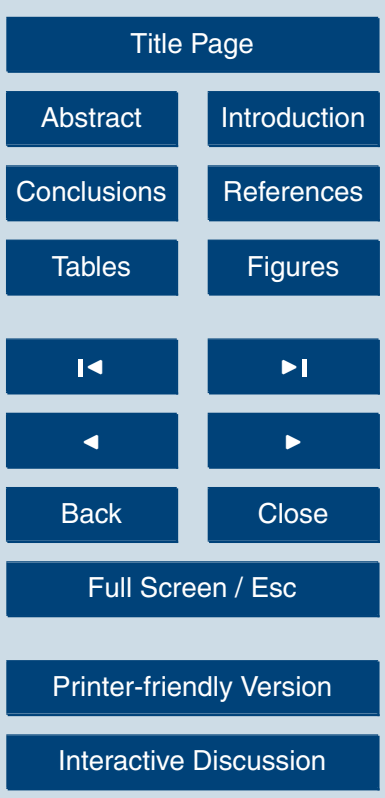


eastern and western jetties (Fig. 1). By changing the type of the berths from open type to quay wall, the hydrodynamics of currents and sediment transport might have unknown effects on sedimentation patterns around and into the neighboring areas i.e. berths for very large vessels to the west of the western jetty and the barge harbor 5 to the east of the eastern jetty. Therefore knowledge of present hydrodynamics patterns and suspended loads in the vicinity of the eastern and western jetties is vital to anticipate land reclamation effects on the flow field and sedimentation processes. In order to achieve a firm understanding of the sediment regime and the flow field pattern in the study area, two $25 \mathrm{~h}$ water samplings were carried out associated with the 10 bottom-mounted ADCP in the barge harbor. In the present work some results of sediment resuspension based on two $25 \mathrm{~h}$ water samplings and ADCP measurements are presented.

\subsection{Point sampling}

Water sampling was carried out in two $25 \mathrm{~h}$ periods during the spring tide and neap 15 tide at station C3 (Fig. 1). Six samples were collected in each hour in vertical profiles aimed to quantify the vertical and temporal variation of the SSC through the water column. Surface water defined as $1 \mathrm{~m}$ below surface (mbs) and bottom water $1 \mathrm{~m}$ above bottom (mab) and four samples equidistant, between surface and bottom, were collected. One litre of water was sampled with decontaminated Automatic Water Sam20 pler Hydro-Bios Multi-Limnos bottles and immediately transferred into pre-cleaned PET bottles $(1000 \mathrm{ml})$, previously rinsed with distilled water. Utilizing Multi-Limnos bottles facilitated near-instantaneous point samples of water and suspended materials through the water column. After recovery, the contents of each bottle designated for measurement of suspended sediments were gravity filtered in the laboratory through a Sartorius $25393,0.2 \mathrm{~mm}$ pore size, $150 \mathrm{~mm}$ diameter, polycarbonate filter. Filter papers were dehumidified in $60^{\circ} \mathrm{C}$ for 120 min prior to filtering and weighed immediately. After filtration, each filter was desalinized by distilled water then placed in a glass plate and oven dried at $60^{\circ} \mathrm{C}$ for $24 \mathrm{~h}$. Difference between filter and filter plus sample weight was used as suspended sediment weight.

\section{OSD}

$8,1601-1630,2011$

\section{Estimating SSC from ADCP backscatter}

P. Ghaffari et al.

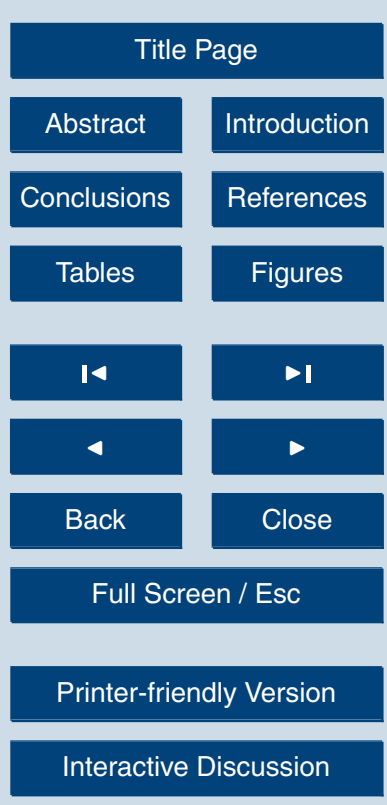




\subsection{Acoustic profiling}

Vertical profiling of SSC was made by an up-ward looking $300 \mathrm{kHz}$ broadband ADCP (RDI) mounted at $40 \mathrm{~cm}$ above the seabed in the barge harbor basin (Fig. 1). The vertical profiles of acoustic backscatters from suspended sediments were measured

5 in range bins with vertical resolution of $1 \mathrm{~m}$ (measuring layer) and temporal resolution of $6 \mathrm{cph}$. In a typical application, bursts of data are taken e.g. for $12 \mathrm{~min}$ each hour and six calibration points for the water column are taken coincidentally using water samples (Shi et al., 2006). In the present study the up-ward ADCP was set to 150 acoustic pulses every $10 \mathrm{~min}$ and ping intervals to Auto (RD Instruments, 2002), 10 therefore 150 pings evenly spaced throughout the entire ensemble. Consequently each hour consisted of 900 profiles of backscatter acoustic energy from suspended materials through the water column which is almost twice the typical profile rate recommended by Shi et al. (2006). Therefore by assuming statistical stationarity, ensemble averaging can be used to improve the signal to noise ratio. These profiles were calibrated using

15 SSC data obtained by the point sampling. The observations by the acoustic method were carried out under the normal MC channel runoff condition. Acoustic profiling of suspended sediment concentration was performed for consecutive spring and neap tides for two semidiurnal tidal cycles i.e. $25 \mathrm{~h}$ recording period for each. A spring tide was monitored for $25 \mathrm{~h}$ (16:00 LT, 23 November to 16:00 LT, 24 November 2006) and neap tide for another $25 \mathrm{~h}$ (14:00 LT, 30 November to 14:00 LT, 1 December 2006).

\section{Data method and processing}

\subsection{Data treatment}

A quality control procedure is performed to eliminate obvious errors and anomalous values that appear temporarily in data sets. In addition to environmental based errors like target speed or data endpoints errors which occasionally appear, some instrumental

\section{OSD}

8, 1601-1630, 2011

\section{Estimating SSC from ADCP backscatter}

P. Ghaffari et al.

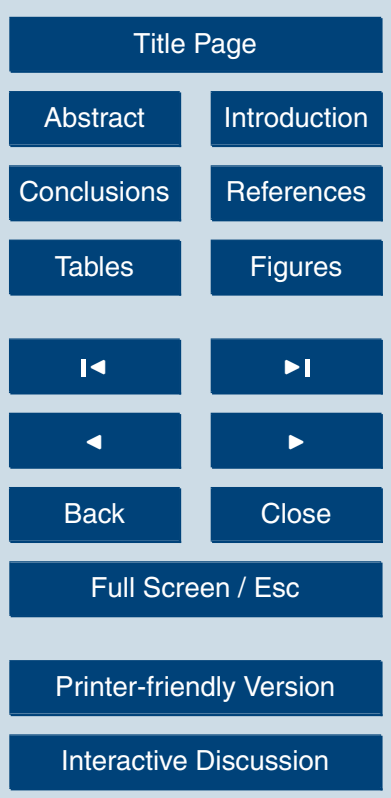


problems could affect ADCP reception quality and be sources for further errors. Additionally environmental noise and relatively dense sea traffic in the $\mathrm{MC}$ channel are the most probable cause for such errors. The spikes were identified by taking first differences (FD) from the original data series in order to achieve second-order station5 ary series that were more steady in mean and variance than the original data. Then a threshold was determined such that within this limit, $99 \%$ of the data is included. Hence those that fell outside the limit were considered as probable error spikes. Fundamentals of the FD method and details of spike identification using FD can be found e.g., in (Free et al., 2004; Kovačević et al., 2004; Peterson et al., 1998). Therefore 10 invalid data were removed and cleaned; de-spiked data were constructed and considered as core for further processing. In order to avoiding phase shift by simply averaging, smooth hourly data were obtained by applying a symmetrical Doodson filter (Pugh, 1987 ) to the original ( $6 \mathrm{cph}$ sampling interval) de-spiked data.

\subsection{Conversion of ADCP backscatter to SSC}

15 Acoustic backscatter intensity (ABS) is sometimes used to survey the concentration of suspended sediment and zooplankton in Broadband ADCPs. Methods for estimating SSC from ABS are still not developed completely and encounter some difficulties based on complicated interactions between suspended particle properties and acoustic waves. The echo intensity of acoustic beams that could be attributed to SSC by 20 using the empirical sonar equation, depend on backscatter coefficient and transmitted power (Gordon, 1996). When the bulk of backscattering particles are of sedimentary nature, the acoustic intensity can be used as proxy for total SSC of the water column. In fact the intensity of the backscatter echo is a function of the instrument and the flow properties. Instrument response is depends to distance from the sensor, working fre25 quency, transmit power, and receiver sensitivity, while the particle size, attenuation due to the water itself, and type and concentration of the suspended particles are the most important flow properties (Alvarez and Jones, 2002). In the basic form for reverberation level, the empirical sonar equation (Urick, 1975) contains terms for the insonified

\section{OSD}

8, 1601-1630, 2011

\section{Estimating SSC from ADCP backscatter}

P. Ghaffari et al.

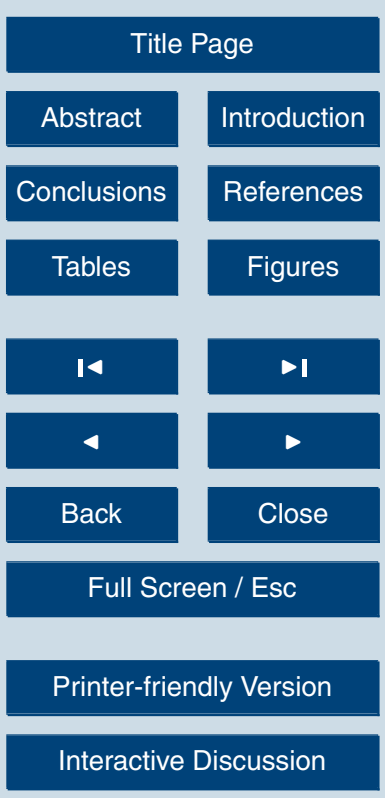


volume, volume scattering strength, source level and two-way pass attenuation. From a practical standpoint, quantifying all required parameters, e.g. characteristics of targets and acoustic sources in order to directly estimate SSC from ABS, is not achievable. To keep it simple we used the sonar equation in an exponential form by relating 5 the SSC to relative backscatter as was utilized by Gartner (2004). The exponential estimation equation is:

$\mathrm{SSC}_{(\mathrm{est})}=10^{(A+B \times \mathrm{RB})}$,

the exponent of Eq. (1) contains a term for the measured relative acoustic backscatter, $\mathrm{RB}$ which is the echo level measured at the transducer plus two-way transmission losses (Thevenot et al., 1992), as well as terms for an intercept, $A$, and slope, $B$. The intercept and slope values could be determined by regression of parallel ABS estimates and traditional measurements of SSC (water sampling and lab procedure) on the semilog plane

$\log \left(\mathrm{SSC}_{\text {measured }}\right)=A+B \times \mathrm{RB}$.

15 According to Thevenot et al. (1992) results, the RB defined as:

$R B=R L+2 T L$,

in this simplified form for reverberation, the sonar equation (Urick, 1975) can be written as

$R L=S L-2 T L+T S$.

20 Here $\mathrm{RL}$ is reverberation level, $\mathrm{SL}$ is the source level, $2 \mathrm{TL}$ is the two-way transmission loss, and TS is the target strength which is dependent on the ratio of wavelength to particle diameter. Sensitivities of acoustic frequencies are different for various particle sizes, and backscatter strength depends on particle size, type and concentration at a particular frequency. Therefore a particular frequency has maximum sensitivity for 25 a specific particle size. Peak sensitivity occurs where the particle circumference is 1609
OSD

8, 1601-1630, 2011

\section{Estimating SSC from ADCP backscatter}

P. Ghaffari et al.

\section{Title Page}

Abstract Introduction

Conclusions References

Tables Figures

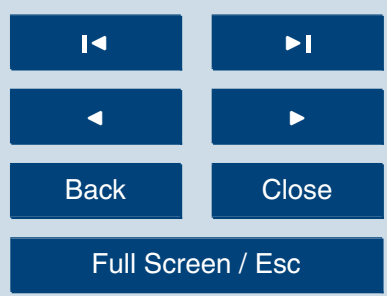

Printer-friendly Version

Interactive Discussion 
equal to the acoustic beam wavelength (Kostaschuk et al., 2005). For a constant type and size of particle, scattering strength is directly proportional to concentration. In fact, in practice, it is not feasible to separate between the portion of particle size and suspended sediment concentration in the acoustic backscatter at a single frequency 5 (Reichel, 1998). Calibration with known values of concentration is therefore required for absolute ADCP-based estimates of concentration. However, a particular calibration is only valid if the size distribution does not change.

In terms of ADCP parameters, $\mathrm{RL}=K_{\mathrm{c}}\left(E-E_{\mathrm{r}}\right)$, where $E$ is ADCP echo intensity and $E_{\mathrm{r}}$ is echo intensity at the reference level (both in counts), and $K_{\mathrm{c}}$ is the scale factor 10 used to convert counts to dB. Also, the two-way transmission loss defined as:

$2 \mathrm{TL}=20 \log (R)+2 \alpha R$,

where, $R$ is range to the ensonified volume (slant range) in metre defined as $R=r+\frac{D}{4}$ ( $r$ is the slant distance from the transducer face to the center of the bin, and $D$ is the bin size), $\alpha$ is absorption coefficient of water and sediment, in $\mathrm{dB} \mathrm{m}^{-1}$. Right hand side 15 terms of Eq. (5) indicate spreading and absorption losses, respectively. Typical values of $E_{\mathrm{r}}, K_{\mathrm{c}}$ and $\alpha$ (for the fixed frequency) for most Broadband Workhorse systems are 40 counts, $0.45 \mathrm{~dB}$ count $^{-1}$ and $0.069 \mathrm{~dB} \mathrm{~m}^{-1}$ (307.2 $\mathrm{kHz}$ ADCPs at $\left.4{ }^{\circ} \mathrm{C}\right)$, respectively (Deines, 1999; Gartner, 2004; Jiang et al., 2007). The two-way transmission loss parameter (2TL) in Eq. (5) consists of the attenuation effects both of sea water and of 20 particles in suspension through the water column.

One of the serious limitations of the ABS method to estimate SSC is the relation between particle size and acoustic frequency. The suitable approach to estimate SSC from acoustic backscatter is the Rayleigh scattering model (Reichel and Nachtnebel, 1994). The majority of the scattering pattern propagates backward whenever the acoustic wavelength is greater than the particle circumference and errors in SSC estimation start to increase as wavelength approaches particle circumference (Flammer, 1962). The acoustic method for estimating SSC may be unsuitable if particle size is too small (Lynch et al., 1994). However, in some estuaries, the presence of combined suspended sediments could supply scattering sizes in the range of the Rayleigh 1610

\section{OSD}

8, 1601-1630, 2011

\section{Estimating SSC from ADCP backscatter}

P. Ghaffari et al.

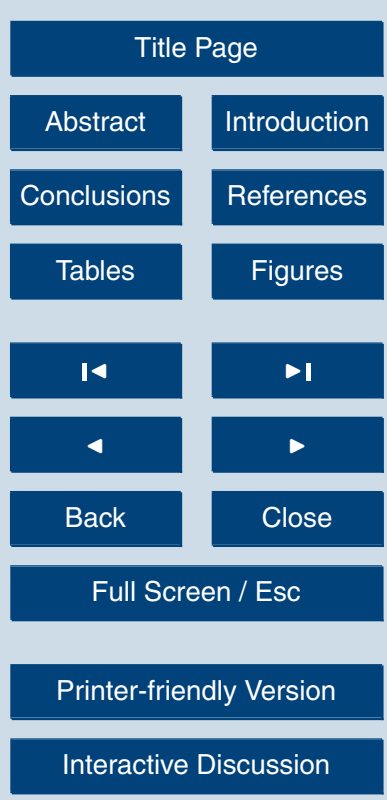


scattering model, albeit the individual particle size is extremely small (Gartner, 2004). Substituting Eqs. (3)-(5) in Eq. (1), a simplified equation can be derived for estimating SSC as follows:

$$
10 \log _{10}(\mathrm{SSC})=C_{\mathrm{k}}+10 \log _{10}\left(R^{2}\right)+2 \alpha R+K_{\mathrm{c}}\left(E-E_{\mathrm{r}}\right) \text {, }
$$

5 where SSC is suspended sediment concentration (in $\mathrm{kg} \mathrm{m}^{-3}$ ), and $C_{\mathrm{k}}$ is a combined constant.

Additionally, the two-way transmission loss also depends on absorption of acoustic energy by the sea-water according to Eq. (5). Published algorithms are based on viscous absorption generated by particle motion and absorption by specific chemicals:

$\alpha=0.106 \frac{f_{1} f^{2}}{f_{1}^{2}+f^{2}} e^{(\mathrm{pH}-8) / 0.56}+0.52\left(1+\frac{T}{43}\right)\left(\frac{S}{35}\right) \frac{f_{2} f^{2}}{f_{2}^{2}+f^{2}} e^{-D / 6}+0.00049 f^{2} e^{-\left(\frac{T}{27}+\frac{D}{17}\right)}$

where $S$ is salinity in ppt, $D$ is water depth in metre, $f$ is the applied acoustic frequency that is $307.2 \mathrm{kHz}$ in this case and $T$ is water temperature in ${ }^{\circ} \mathrm{C}$. The first and second terms at the right hand side of Eq. (7) are absorption by chemicals where $f_{1}$ and $f_{2}$ are two principal components of the ocean which contribute as Boric acid $\left(f_{1}\right)$, and Magnesium sulphate $\left(f_{2}\right)$ relaxation frequencies (Ainslie and McColm, 1998). The last right hand side term represents viscous absorption.

\section{Results and discussion}

\subsection{Calibration and validation procedure}

Utilizing Eq. (7) and substituting the study area environmental conditions $\left(T=20^{\circ} \mathrm{C}\right.$, $D=10 \mathrm{~m}, S=39 \mathrm{ppt}, \mathrm{pH}=7.5), \alpha$ is determined as $0.118581 \mathrm{~dB} \mathrm{~m}^{-1}$. Then Eq. (6) could be utilized to estimate a profile of SSC. To estimate a time series of SSC from ABS time series data, the following practical approaches were used. The available cast
OSD

$8,1601-1630,2011$

\section{Estimating SSC from ADCP backscatter}

P. Ghaffari et al.

\section{Title Page}

Abstract Introduction

Conclusions References

Tables Figures

14

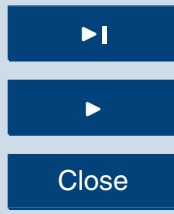

Back

Close

Full Screen / Esc

Printer-friendly Version

Interactive Discussion 
data were separated with $5: 1$ ratio into two datasets by using a random number generator. The first dataset was used to calibrate Eq. (2), i.e., using lab based SSC and echo intensity data in $\mathrm{dB}, A$ and $B$ values in regression respectively are $-1.5863,0.0060728$ (Fig. 2). The second group of data is used to verify the accuracy of the estimated 5 SSC. Substituting $A$ and $B$ values in Eq. (1) and applying them to the second group of acoustic backscatter data, we estimated SSC. In order to validate the estimated SSC, the second group lab based conventional SSC is shown in Fig. 3 against the acoustic backscatter estimates of SSC. Besides the qualitative compatibility of the measured and estimated SSC, Fig. 3 illustrates a rather high correlation between lab based and 10 acoustic based particles in suspension $\left(R^{2}=88 \%\right)$. Comparing the $1: 1$ line with the best-fit linear regression line, the ADCP-based SSC estimates are slightly lower than the measured SSC. This under estimation, which is not very high, certainly falls within the error of a lot of experimental methods. In general, the acoustic method (ADCP) tends to underestimate SSC at times of smaller size distribution. This trend is reversed 15 when the size distribution become larger (Gartner, 2004; Lynch et al., 1994; Hamilton et al., 1998). Most probably the local resuspension and advection played important and variable roles in producing a temporally varying size distribution (including large aggregate, sand and silt).

The procedure of estimate SSC from ABS is a convoluted process that consists of: calculating transmission lost from spreading and absorption; calculating relative backscatter by subtracting reference level; and finally determining interception and slope against a traditionally measured SSC. The procedure of estimating SSC from ABS may provide some acceptable values of acoustic based SCC under favorable circumstances. Additionally the method has the single frequency sensor limitation of being unable to differentiate between changes in size distribution and concentration (Gartner, 2004). Flow velocity measurements (providing speed profiles instead of single-point records) coincide with estimating SSC profiles, without using additional instruments, make this method advantageous relative to other methods. Acceptable correlation between point sampling and acoustic based SSC suggest that the acoustic
OSD

$8,1601-1630,2011$

\section{Estimating SSC from ADCP backscatter}

P. Ghaffari et al.

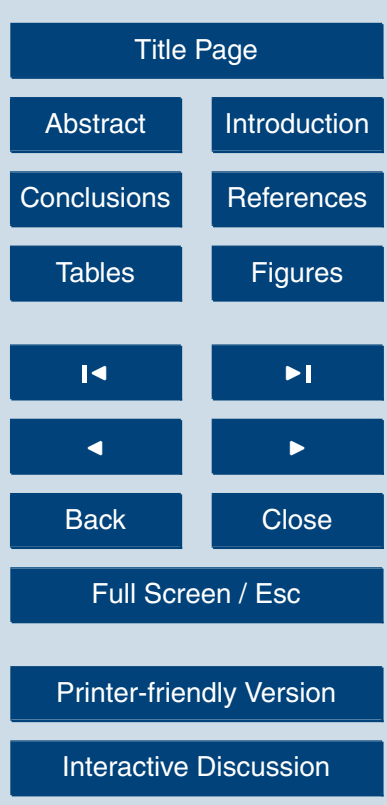

1612 
method could replace the traditional method for measuring SSC an the MC. In fact the acoustic method has high temporal and spatial resolution.

\subsection{Relation between flow field and sediment in suspension}

Figures 4 and 5 show time series data of tidal elevation, current speed and direction 5 by ADCP during spring and neap tides, respectively. Those data were analyzed for spring/neap tidal (ebb/flood) hydrodynamics at the MC of the PG. Currents were mainly tidal (semidiurnal). Current speed was modulated fortnightly, reaching its maximum amplitude of $28.13 \mathrm{~cm} \mathrm{~s}^{-1}$ during the spring tide (Fig. 4), and maximum amplitude of $27.64 \mathrm{~cm} \mathrm{~s}^{-1}$ during the neap tide (Fig. 5).

10 Over the spring-neap tidal cycle, the two $25 \mathrm{~h}$ observations revealed significant variation in the tidal current at the MC. Spring (neap) tidal current amplitudes are about $30-40 \%$ higher (lower) than the averaged values. Such changes in the amplitudes of tidal currents could cause drastic changes in the mixing, vertical stratification and also SSC in the estuary. However, it is not known how the spring-neap tidal cycle affects 15 the stratification and circulation in the main channel of the MC. Both spring and neap tidal currents show asymmetric behavior on ebb and flood tides. While the maximum tidal current amplitudes occur for ebb tides, both spring and neap show weaker currents during flood tides. Therefore there is an ebb dominated system between high and low tides. As shown in Figs. 4 and 5, during spring and neap tides, the current speed generally increases from the bottom to the surface. Table 1 demonstrates some statistics of the flow field during spring and neap tides at the study area, current speed ranged from 28.132 to $0.1 \mathrm{~cm} \mathrm{~s}^{-1}$ and 27.645 to $0.141 \mathrm{~cm} \mathrm{~s}^{-1}$ at spring and neap tides, respectively.

Currents directions show a slight rotation in a clockwise sense with the tidal ellipse 25 and maximum currents for the spring and neap tides occur during the ebb. Approaching to the high and the low water level in spring and neap in terms of current velocity variations are almost the same, and no significant difference in direction between the upper and lower water column is distinguishable. Although tidal motion rotates clockwise in 
the study area, considering Fig. 6 it is evident that the flow field tends to be along channel in an east-west direction and shows an westward discharge condition at spring and neap tides. Since the monitoring station was located at the main channel of the MC, tidal forcing can be expected as the main cause of fine sediment resuspension.

\section{4.3 Suspended sediment concentrations}

As illustrated in Figs. 7 and 8, calibrated acoustic images generally revealed a bursttype dynamic nature of fine suspended sediment concentrations at spring and neap tides. The suspensions are locally stirred as a short lasting event and propagate away. Such sharp resuspension events (distinguishable as red color signals on acoustic SSC images in spring and neap tides) lasted only one hour or less, depending on dynamic processes. Relatively short period sediment suspensions maybe attributed to impinge events of burst type turbulences. High concentrations of particles in suspension were evident over intertidal (flood/ebb) cycles. Although transport processes were extended to the whole water column during the spring tide, large suspended loads were contained mainly within the lower part of the water column (Fig. 7). High concentration was present mainly in the ebb tide, distributed through the water column (e.g. from 16:00 23 November to 18:00 23 November) and after high water during the ebb tide up to the starting flood tide (e.g., from 02:00 24 November to 10:00 24 November). The flow pattern in the spring tide (Fig. 4), illustrates that strong currents on ebb tides are 20 responsible for dispersing fine sediments. During neap tides, concentration is generally comparable with that at spring tides (Fig. 8) and high concentrations of SSC are evident in ebb tides, despite the fact that the currents and turbulence were too weak to disperse sediment. The asymmetry between the ebb and flood tides and the total shear exerted by them on the MC is considerable. The total ebb shear is significantly

higher than the flood, resulting in a greater amount of erosion and suspension during the ebb tides. In the MC significant deformation of the tidal waves occurs due to the fact that the ebb tides propagate faster than flood tides. This asymmetry will be significantly magnified with respect to the bed shear, which is a function of the square of the
OSD

$8,1601-1630,2011$

\section{Estimating SSC from ADCP backscatter}

P. Ghaffari et al.

\section{Title Page}

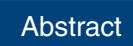

Introduction

Conclusions

References

Tables

Figures

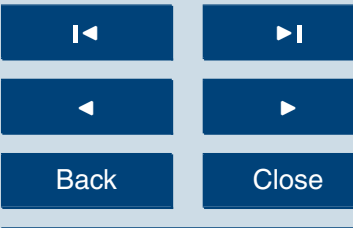

Full Screen / Esc

Printer-friendly Version

Interactive Discussion 
current velocity. Since the rate of the erosion of the cohesive sediments are a direct function of the bottom shear stress (Allen et al., 1980), the higher ebb tides velocities will cause a greater bottom erosion.

There is a remarkable correlation between tidal phase and the recorded level of parti5 cles in suspension. The highest suspended load concentrations seem to occur almost consistently at the same section of the tidal cycle i.e., ebb tide, for spring and neap tides. Comparing the onset time of increased suspended sediment concentration with current magnitude implies a threshold speed for suspension of $10 \mathrm{~cm} \mathrm{~s}^{-1}$. Threshold current velocity for sediment suspension could be applicable for numerical model cali10 bration for the study area (Shi et. al., 2006). Additionally the efficient role of spring and neap cycle on fine sediment suspension and even transport processes is suggested by our data.

\subsection{Significance of fine-sediment plumes}

Plumes of particles in suspension were induced by the tidal currents. Remarkable re15 suspended fine sediments from the bed which caused vertical stratification of the water column were evident during strong spring tides. Moving suspended particles can impulsively collide with particles on the bed, thereby knocking and releasing them. The high sediment concentrations could be considered as a probable mechanism to induce more erosion. Near-bed (4 mab) episodic resuspension of fine sediment plumes is de20 picted in Figs. 7 and 8 . These processes could enhance turbulence and consequently affect the fine sediment transport. According to the calibrated acoustic based SSC images, fine sediment-induced plumes, were generally reinforced and more prominent in the spring tide period (Fig. 7) compared with the neap period (Fig. 8). Therefore it can be suggested that fine sediments plume were responsible for possible fine sediment transport during spring tides at the MC. Fine sediment plumes detached from seabed under the influence of tidal flow could damp turbulence as gravity acts against upward excitations of the particles in suspension. On the other hand, in stable stratification, downward oscillations of particles are opposed significantly by lower layers holding

\section{OSD}

$8,1601-1630,2011$

\section{Estimating SSC from ADCP backscatter}

P. Ghaffari et al.

\section{Title Page}

Abstract Introduction

Conclusions References

Tables Figures

\begin{tabular}{|c|c|}
\hline I4 & $\bullet$ \\
\hline Back & Close \\
\hline Full Screen / Esc \\
\hline
\end{tabular}

Printer-friendly Version

Interactive Discussion 
denser particle suspensions, even at very low concentrations (Toorman et al., 2002). Drag reduction could occur under the influence of tidally- forced fine sediment plumes.

There are several studies on vertical fine sediment transport processes around the world's estuaries which are intensively reviewed in Shi et al. (2006). In the present 5 study vertical velocity resolution is very low ( $1 \mathrm{~m}$ bin layer) yielding only eight records at maximum water elevation, as illustrated in Figs. 7 and 8 . For instance, the bottom velocity count was obtained at 4.0 mab. Therefore the recorded velocity data are insufficient to quantitatively interpret the vertical fine sediment processes, but the relatively high resolution acoustic data shed some light on the local fine sediment processes at 10 the barge harbor of the MC, i.e., the deposition, resuspension and fine sediment driven stratification. As illustrated in Figs. 4, 5 and 7, 8 suspended sediment concentration became high when the tidal current is greatest, revealing that local characteristics, i.e. local deposition and suspension, control suspended sediment plumes at the MC. The relation of tidal currents (at spring and neap tide) with releasing and re-floating of bed sediments, and eventually causing vertical stratification of the water column, is fairly illustrated by calibrated acoustic backscatter data. The calibrated acoustic images further suggested that high speed currents, enabling bed particles to gain adequate energy for resuspension, could be attributed to the both spring and neap tides period. In general field observation suggests a complex flow field and hydrodynamics characteristics in the MC of the PG. Moreover it demonstrates a complex interaction among the tidal features (elevations, speed and direction) and fine sediment processes (erosion, transport and deposition) in the barge harbor of MC. The sediment is transported under the current energy influence at the MC, thereby fluctuating fine sediment resuspension and changing the sediment flux, particularly in the bottom part of the water column; morphodynamical processes are induced and bottom morphology is changing by current action in the study area.

OSD

$8,1601-1630,2011$

\section{Estimating SSC from ADCP backscatter}

P. Ghaffari et al.

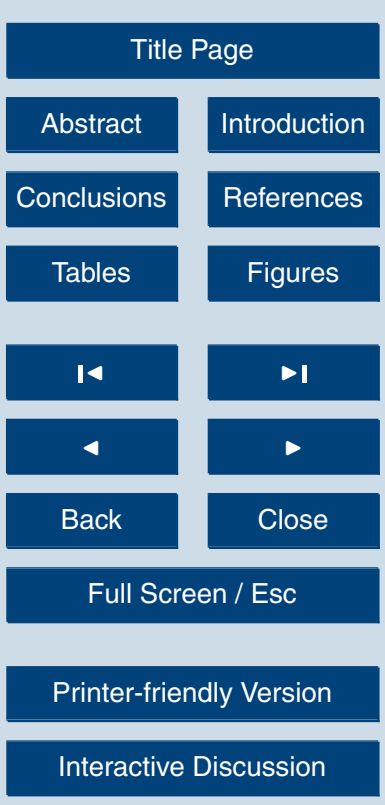


The outputs of suspended sediment concentration and transport processes could be applicable for study of contaminant associated to fine sediment plumes in turbid estuaries. The calibrated suspended sediment concentration images also could be applicable to calibrate models and provide some better understanding regarding the 5 dynamics and fate of contaminants attached to sediment in the $\mathrm{MC}$ and its main tributaries. In order to get better understanding of fine-sediment induced plume dynamics, current field studies should be integrated with a numerical model in the MC.

\section{Concluding remarks}

Utilizing acoustic backscatter data to quantify sediment concentration in estuaries and 10 turbid flow fields is getting to be more common owing to its advantages over other methods. In this work, two $25 \mathrm{~h}$ ADCP data sets in one spring-neap cycle were examined in order to investigate the sediment regime of the MC. Coincident with ADCP reading, traditional sediment samplings were carried out by hourly vertical profiles aiming to quantify the vertical and temporal distribution of SSC with the intention of calibration of 15 ADCP backscatter profiles.

Data sets were obtained during the project entitled Study on hydrodynamics and sediment transport in Imam Port Complex by the Iranian Ports and Maritime Organization (PMO). Field measurements and data processing were carried out by the department of physical oceanography of the Iranian National Institute for Oceanography (INIO), from November to December 2006. ADCP backscatter data and lab-based sediment data were divided into two segments; the first data segment was used for calibration and the second group was used to verify the accuracy of estimated SSC.

Based on field measurements and analyses it was concluded that:

- Acoustic based suspended loads could be evaluated utilizing the acoustic backscatter intensity by determining two-way transmission loss, calculating relative backscatter and attributing relative backscatter to suspended loads.

\section{OSD}

$8,1601-1630,2011$

\section{Estimating SSC from ADCP backscatter}

P. Ghaffari et al.

\section{Title Page}

Abstract Introduction

Conclusions References

Tables Figures

\begin{tabular}{|c|c|}
\hline I & \multicolumn{1}{|c|}{} \\
\hline Back & Close \\
\hline Full Screen / Esc \\
\hline
\end{tabular}

Printer-friendly Version

Interactive Discussion 
- Although the ADCP-based SSC is a slight underestimate, the estimated SSC from the acoustic technique showed acceptable correlation with lab-based SSC. In fact the results indicate that the calculated suspended loads agree well with the traditional observed results, therefore ADCP-based sediment monitoring could be considered as a practical method to evaluating accurate and time series of suspended loads in turbid estuaries.

- Backscatter data revealed the complicated dynamical nature of suspended sediments in a spring-neap cycle. Due to the asymmetric behavior of tidal currents in the study area and different current pattern in ebb and flood tides, suspended load concentrations are remarkably high on ebb tides. In other words, owing to large magnitudes of currents in the ebb tides, sediments gain sufficient energy to refloat and suspend more freely. Additionally onset time of increasing suspended loads enables an estimate of threshold velocity for sediment re-suspension in the MC estuary system.

- While the maximum SSC are evident during spring tides, the neap tide shows less concentration of suspended sediments, comparing with the spring tide, and higher concentrations of suspended loads are noticeable at bottom layers.

Although due to high vertical and temporal variability of SSC in the MC, a long term measurement could be useful in order to capture SSC patterns in the MC estuary system, but as a semidiurnal tidal system is dominant, the present measurements provide a significant time series of suspended loads in the study area. According to current data and relatively high resolution backscatter intensities, it could be concluded that sediment processes at the barge harbor are fairly correlated with tidal currents. Therefore possible changes in tidal current regime by modifying the berths from open type to quay wall could be a potential cause for sediment regime change in the barge harbor.

\section{OSD}

$8,1601-1630,2011$

\section{Estimating SSC from ADCP backscatter}

P. Ghaffari et al.

\section{Title Page}

Abstract Introduction

Conclusions References

Tables Figures

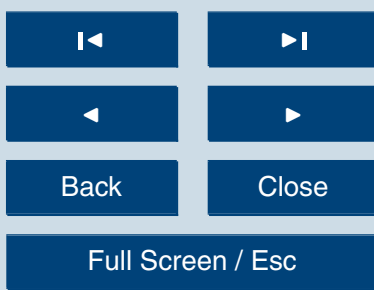

Printer-friendly Version

Interactive Discussion 
Acknowledgements. Authors acknowledge Iranian ports and Maritime organization (PMO), Ministry of Transportation and Pooya Tarh Pars Consulting Engineers Company for their financial and administrative supports. We would like to acknowledge the Iranian National Institute for Oceanography (INIO) for providing ADCP backscatter and traditional SSC data. Additionally

5 authors acknowledge John M. Huthnance for editing and standardizing the English language of manuscript.

\section{References}

Ainslie, M. A. and McColm, J. G.: A simplified formula for viscous and chemical absorption in sea water, J. Acoust. Soc. Am., 103, 1671-1672, 1998.

10 Allen, G. P., Salamon, J. C., Bassouliet, P., Du Penhoat, Y., and De Grandpre, C.: Effects of tides mixing and suspended sediment transport in macrotidal estuaries, Sediment. Geol., 26, 69-90, 1980.

Alvarez, L. G. and Jones, S. E.: Factors influencing suspended sediment flux in the upper gulf of California, Estuar. Coast. Shelf S., 54, 747-759, 2002.

15 Chen, S.-L., Zhang, G.-A., Yang, S.-L., and Shi, J. Z.: Temporal variations of fine suspended sediment concentration in the Changjiang River estuary and adjacent coastal waters, China, J. Hydrol., 331, 137-145, 2006.

Deines, K. L.: Backscatter Estimation Using Broadband Acoustic Doppler Current Profilers. IEEE Sixth Working Conference on Current Measurement, IEEE, San Diego, California, 201999.

Downing, J. P.: Suspended sediment and turbidity measurements in streams: what the do and do not mean. Aoutomatic Water Quality Monitoring Workshop, Richmond, B. C., 1996.

Dyer, K. R.: Estuaries: A Physical Introduction, 2nd edn., John Wiley and Sons, Chicester, West Sussex, England, 1997.

25 Flammer, G. H.: Ultrasonic measurement of suspended sediment, US Geological Survey Bulletin 1141-A, 48 pp., 1962.

Free, M., Angell, J. K., Durre, I., Lanzante, J., Peterson, T. C., and Seidel, D. J.: Using first differences to reduce inhomogeneity in radiosonde temperature datasets, J. Climate, 17, 4171-4179, 2004.

30 Gartner, J. W.: Estimating suspended solid concentrations from backscatter intensity measured

OSD

8, 1601-1630, 2011

\section{Estimating SSC from ADCP backscatter}

P. Ghaffari et al.

\section{Title Page}

Abstract Introduction

Conclusions

References

Tables

Figures

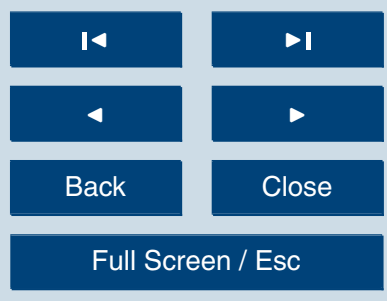

Printer-friendly Version

Interactive Discussion 
by acoustic Doppler current profiler in San Francisco Bay, California, Mar. Geol., 211, 169187, 2004.

Gordon, R. L.: Acoustic Doppler Current Profiler: Principles of operation, a paractical primer, RD Instruments, San Diago, California, 1996.

5 Hamilton, L. J., Shi, J. Z., and Zhang, S. Y.: Acoustic backscatter measurements of estuarine suspended cohesive sediment concentration profiles, J. Coastal Res., 14, 1213-1224, 1998.

Hammond, D. E., Fuller, C., Harmon, D., Hartman, B., Korosec, M., Miller, L. G., Rea, R., Warren, S., Berelson, W., and Hager, S. W.: Benthic flaxes in San Francisco Bay, Hydrogiologia, 129, 22, 1985.

10 Hay, A. E. and Sheng, J.: Vertical profiles of suspended sand concentration and size from multi-frequency, J. Geophys. Res., 97, 15661-15677, 1992.

Holdaway, G. P., Thorne, P. D., Flatt, D., Jones, S. E., and Prandle, D.: Comparison between $\mathrm{ADCP}$ and transmissometer measurements of suspended sediment concentration, Cont. Shelf Res., 19(3), 421-441, 1999.

15 Iran Gulf: http://www.irangulf.com/ports_mahshahr.htm, last access: 2 July 2011, 2011.

Jiang, S., Dickey, T. D., Steinberg, D. K., and Madin, L. P.: Temporal variability of zooplankton biomass from ADCP backscatter time series data at the Bermuda Testbed Mooring site, Deep-Sea Res. Pt. I, 54, 608-636, 2007.

Kostaschuk, R., Best, J., Villard, P., Peakall, J., and Franklin, M.: Measuring flow velocity and sediment transport withan acoustic Doppler current profiler, Geomorphology, 68, 25-37, 2005.

Kovačević, V., Gačić, M., Mancero Mosquera, I., Mazzoldi, A., and Marinetti, S.: HF radar observations in the northern Adriatic: surface current field in front of the Venetian Lagoon, J. Marine Syst., 51, 95-122, 2004.

Longdill, P. C. and Healy, T. R.: Sediment dynamics surrounding a flood tidal delta adjecent to reclamation and a dredges turning basin, J Coastal Res., 23, 1097-1105, 2007.

Lynch, J. F., Irish, J. D., Sherwood, C. R., and Agrawal, Y. C.: Determining suspended sediment particle size information from acoustical and optical backscatter measurements, Cont. Shelf Res., 14 (10/11), 1139-1165, 1994.

30 Murphy, P. L. and Valle-Levinson, A.: Tidal and residual circulation in the St. Andrew Bay system, Florida, Cont. Shelf Res., 28(11), 2678-2688, 2008.

Osborne, P. D., Vincent, C. E., and Greenwood, B.: Measurement of suspended sand concentrations in the nearshore: field intercomparison of optical and acoustic backscatter sensors,
OSD

$8,1601-1630,2011$

\section{Estimating SSC from ADCP backscatter}

P. Ghaffari et al.

\section{Title Page}

Abstract Introduction

Conclusions References

Tables

Figures

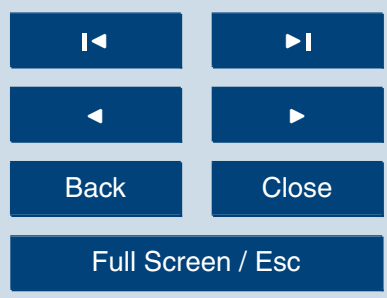

Printer-friendly Version

Interactive Discussion 
Cont. Shelf Res., 14, 159-174, 1994.

Peterson, T., Karl, T., Jamason, P., Knight, R., and Easterling, D.: First difference method: maximizing station density for the calculation of long-term global temperature change, J. Geophys. Res., 103, 25967-25974, 1998.

5 Pugh, D. T.: Tides, Surges and Mean Sea-Level, John Wiley and Sons, Chichester, UK, 1987. RD Instruments: WinSC and PlanADCP users guide, 38, 2002, Acoustic Doppler Solution: http://www.rdinstruments.com/support/documentation/cc_documents.aspx\#workhorse/, last access: 2 July 2011, 2011.

Reichel, G.: Suspended sediment monitoring: use of acoustic Doppler current profiler, in: Encyclopedia of Hydrology and Water Resources, edited by: Herschy, R. W. and Fairbridge, R. W., Kluwer Academic Publishers, The Netherlands, 1998.

Reichel, G. and Nachtnebel, H. P.: Suspended sediment monitoring in a fluvial environment: advantages and limitations applying an acoustic Doppler current profiler, Water Res., 28, 751-761, 1994.

Shi, J. Z., Zhang, S. Y., and Hamilton, L. J.: Bottom fine sediment boundary layer and transport processes at the mouth of the Changjiang Estuary, China, J. Hydrol., 327, 276-288, 2006.

Thevenot, M. M., Prickett, T. L., and Kraus, N. C.: Tylers Beach, Virginia, dredged material plume monitoring project 27 September to 4 October 1991, Dredging Research Program Technical Report DRP-92-7, US Army Corps of Engineers, Washington, DC, 1992.

20

Thorne, P. D., Vincent, C. E., Harcastle, P. J., Rehman, S., and Pearson, N.: Measuring suspended sediment concentrations using acoustic backscatter devices., Mar. Geol., 98, 7-16, 1991.

Toorman, E. A., Bruens, A. W., Kranenburg C., and Winterwerp, J. C.: Interaction of Suspended Cohesive Sediment and Turbulence, in: Proceedings in marine science, Vol. 5: Fine sediment dynamics in the marine environment, edited by: Winterwerp, J. C. and Kranenburg, C., 7-23, 2002, Elsevier Science, Amsterdam.

Urick, R. J.: Principles of Underwater Sound McGraw Hill, Newyork, 1975.

Webster, T. and Lemckert, C. J.: Sediment resuspension within a microtidal estuary/embayment and the implication to channel management, J. Coastal Res. 753-759, 2002.

30 Yuan, Y., Wei, H., Zhao, L., and Jiang, W.: Observations of sediment resuspension and settling off the mouth of Jiaozhou Bay, Yellow Sea, Cont. Shelf Res., 28, 2630-2643, 2008.

\section{OSD}

$8,1601-1630,2011$

\section{Estimating SSC from ADCP backscatter}

P. Ghaffari et al.

\section{Title Page}

Abstract Introduction

Conclusions References

Tables

Figures

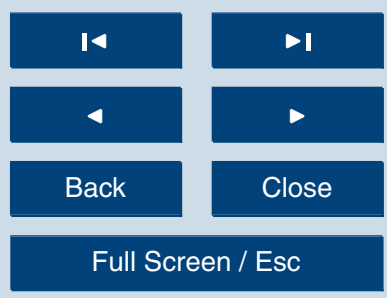

Printer-friendly Version

Interactive Discussion 
Table 1. Some statistics of flow field in spring-neap tides at the study area. Statistics are shown for consecutive layers from $4 \mathrm{mab}$ up to surface in $1 \mathrm{~m}$ been and the velocities are in $\mathrm{cm} \mathrm{s}^{-1}$.

\begin{tabular}{|c|c|c|c|c|c|c|c|c|}
\hline $\begin{array}{l}\text { Spring Tide } \\
\text { Depth (mab) }\end{array}$ & 4 & 5 & 6 & 7 & 8 & 9 & 10 & 11 \\
\hline \multicolumn{9}{|c|}{ Zonal current component } \\
\hline $\operatorname{Max}\left(\mathrm{cm} \mathrm{s}^{-1}\right)$ & 24.9 & 24.9 & 24.5 & 22.1 & 25.0 & 5.20 & 7.90 & -5.30 \\
\hline $\operatorname{Min}\left(\mathrm{cm} \mathrm{s}^{-1}\right)$ & -21.4 & -23 & -21.7 & -22.6 & -21.2 & -23.1 & -23.2 & -17.5 \\
\hline Mean $\left(\mathrm{cm} \mathrm{s}^{-1}\right)$ & -1.62 & -2.13 & -1.99 & -3.17 & -5.0 & -8.75 & -11.9 & -13.12 \\
\hline Variance $\left(\mathrm{cm} \mathrm{s}^{-1}\right)^{2}$ & 97.5 & 104.3 & 106.6 & 107.2 & 92.2 & 75.8 & 90.2 & 12.8 \\
\hline \multicolumn{9}{|c|}{ Meridional current component } \\
\hline $\operatorname{Max}\left(\mathrm{cm} \mathrm{s}^{-1}\right)$ & 15.8 & 12.5 & 11.3 & 14.5 & 12.9 & 3.80 & 2.10 & 2.50 \\
\hline $\operatorname{Min}\left(\mathrm{cm} \mathrm{s}^{-1}\right)$ & -11.1 & -11.3 & -13.1 & -15.2 & -10.8 & -12.2 & -12.4 & -10.4 \\
\hline Mean $\left(\mathrm{cm} \mathrm{s}^{-1}\right)$ & -2.15 & -2.60 & -2.67 & -3.18 & -3.08 & -3.68 & -4.67 & -3.90 \\
\hline $\begin{array}{l}\text { Variance }\left(\mathrm{cm} \mathrm{s}^{-1}\right)^{2} \\
\text { Current magnitude }\end{array}$ & 26.9 & 19.5 & 18.6 & 22.9 & 15.2 & 10.4 & 10.9 & 13.1 \\
\hline $\operatorname{Max}\left(\mathrm{cm} \mathrm{s}^{-1}\right)$ & 26.15 & 27.23 & 26.38 & 25.19 & 28.13 & 26.12 & 25.12 & 17.95 \\
\hline $\operatorname{Min}\left(\mathrm{cm} \mathrm{s}^{-1}\right)$ & 0.1 & 0.53 & 0.5 & 0.80 & 0.90 & 1.21 & 2.32 & 7.36 \\
\hline Mean $\left(\mathrm{cm} \mathrm{s}^{-1}\right)$ & 9.55 & 9.39 & 9.67 & 10.35 & 10.02 & 11.33 & 14.62 & 14.18 \\
\hline Variance $\left(\mathrm{cm} \mathrm{s}^{-1}\right)^{2}$ & 39.71 & 46.38 & 42.12 & 42.39 & 40.94 & 47.26 & 51.31 & 10.68 \\
\hline \multicolumn{9}{|c|}{$\begin{array}{l}\text { Neap Tide } \\
\text { Zonal current component }\end{array}$} \\
\hline $\operatorname{Max}\left(\mathrm{cm} \mathrm{s}^{-1}\right)$ & 23.6 & 25.4 & 25.3 & 27.3 & 6.8 & 8.8 & -13.1 & \\
\hline $\operatorname{Min}\left(\mathrm{cm} \mathrm{s}^{-1}\right)$ & -18.8 & -19.1 & -20.9 & -19.4 & -22.7 & -20.7 & -20.0 & \\
\hline Mean $\left(\mathrm{cm} \mathrm{s}^{-1}\right)$ & -1.25 & -1.66 & -1.87 & -2.27 & -6.7 & -7.8 & -15.9 & \\
\hline Variance $\left(\mathrm{cm} \mathrm{s}^{-1}\right)^{2}$ & 87.6 & 95.9 & 96.88 & 92.0 & 58.3 & 61.4 & 4.6 & \\
\hline \multicolumn{9}{|c|}{ Meridional current component } \\
\hline $\operatorname{Max}\left(\mathrm{cm} \mathrm{s}^{-1}\right)$ & 17.2 & 14 & 11.3 & 7.4 & 6.5 & 3.2 & 4.5 & \\
\hline $\operatorname{Min}\left(\mathrm{cm} \mathrm{s}^{-1}\right)$ & -9.3 & -9.4 & -10.6 & -10.7 & -9.0 & -8.1 & -5.3 & \\
\hline Mean $\left(\mathrm{cm} \mathrm{s}^{-1}\right)$ & -0.97 & -1.77 & -1.88 & -2.3 & -2.7 & -2.8 & -0.2 & \\
\hline $\begin{array}{l}\text { Variance }\left(\mathrm{cm} \mathrm{s}^{-1}\right)^{2} \\
\text { Current magnitude }\end{array}$ & 26.5 & 19.9 & 13.6 & 10.8 & 9.1 & 7.6 & 7.2 & \\
\hline $\operatorname{Max}\left(\mathrm{cm} \mathrm{s}^{-1}\right)$ & 27.64 & 27.26 & 25.63 & 27.49 & 24.42 & 21.50 & 20.00 & \\
\hline $\operatorname{Min}\left(\mathrm{cm} \mathrm{s}^{-1}\right)$ & 0.22 & 0.41 & 0.4 & 0.14 & 0.82 & 1.89 & 13.85 & \\
\hline Mean $\left(\mathrm{cm} \mathrm{s}^{-1}\right)$ & 8.85 & 9.09 & 8.97 & 8.67 & 8.77 & 10.27 & 16.12 & \\
\hline Variance $\left(\mathrm{cm} \mathrm{s}^{-1}\right)^{2}$ & 37.78 & 38.68 & 36.58 & 37.77 & 34.51 & 31.56 & 3.81 & \\
\hline
\end{tabular}

OSD

8, 1601-1630, 2011

\section{Estimating SSC from ADCP backscatter}

P. Ghaffari et al.

Title Page

\begin{tabular}{|c|c|}
\hline Abstract & Introduction \\
\hline Conclusions & References \\
\hline Tables & Figures \\
\hline I & \\
\hline 4 & $\bullet \mathbf{I}$ \\
\hline Back & - \\
\hline Full Screen / Esc \\
\hline
\end{tabular}

Printer-friendly Version

Interactive Discussion 


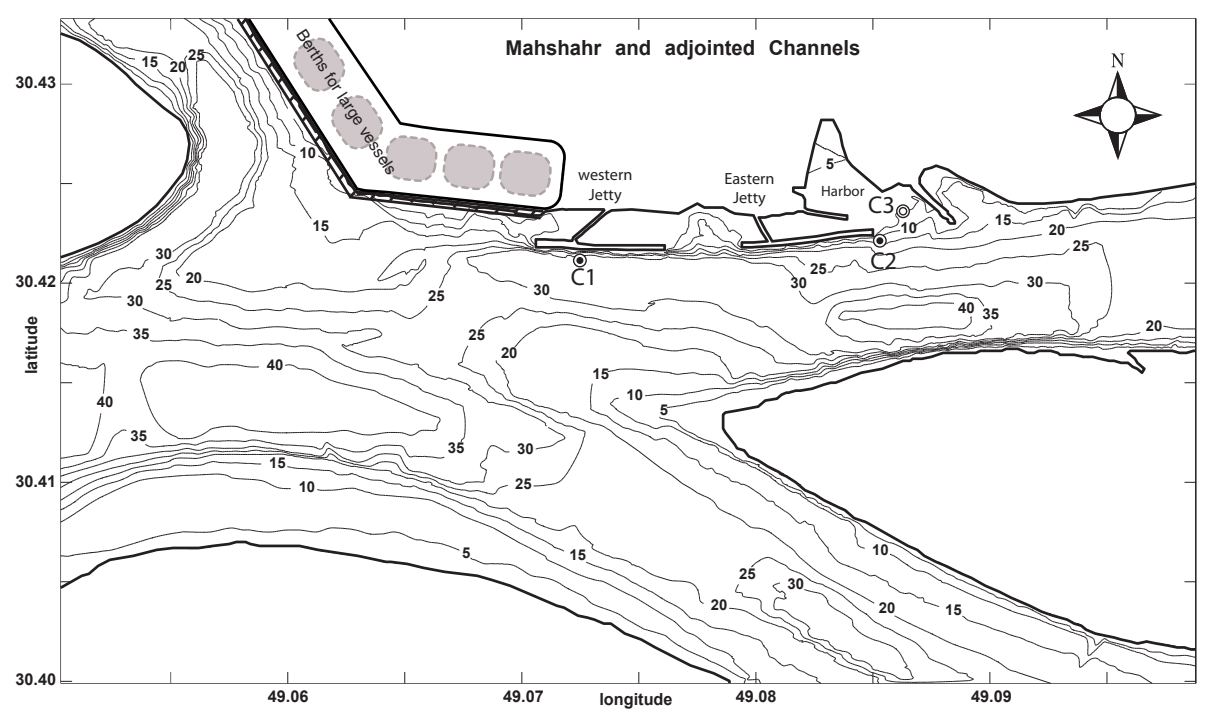

Fig. 1. The study area at the Mahshahr channel in the north western part of the Persian Gulf. C3 shows the deployment location of the $25 \mathrm{~h}$ bottom mounted ADCP in the barge. The eastern and the western wharfs which are two most important berths of the port in vicinity of the barge harbor.

\section{OSD}

$8,1601-1630,2011$

\section{Estimating SSC from ADCP backscatter}

P. Ghaffari et al.

Title Page

\section{Abstract}

Introduction

Conclusions

References

Tables

Figures

14

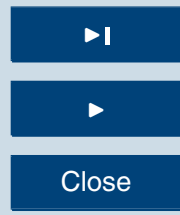

Back

Close

Full Screen / Esc

Printer-friendly Version

Interactive Discussion 


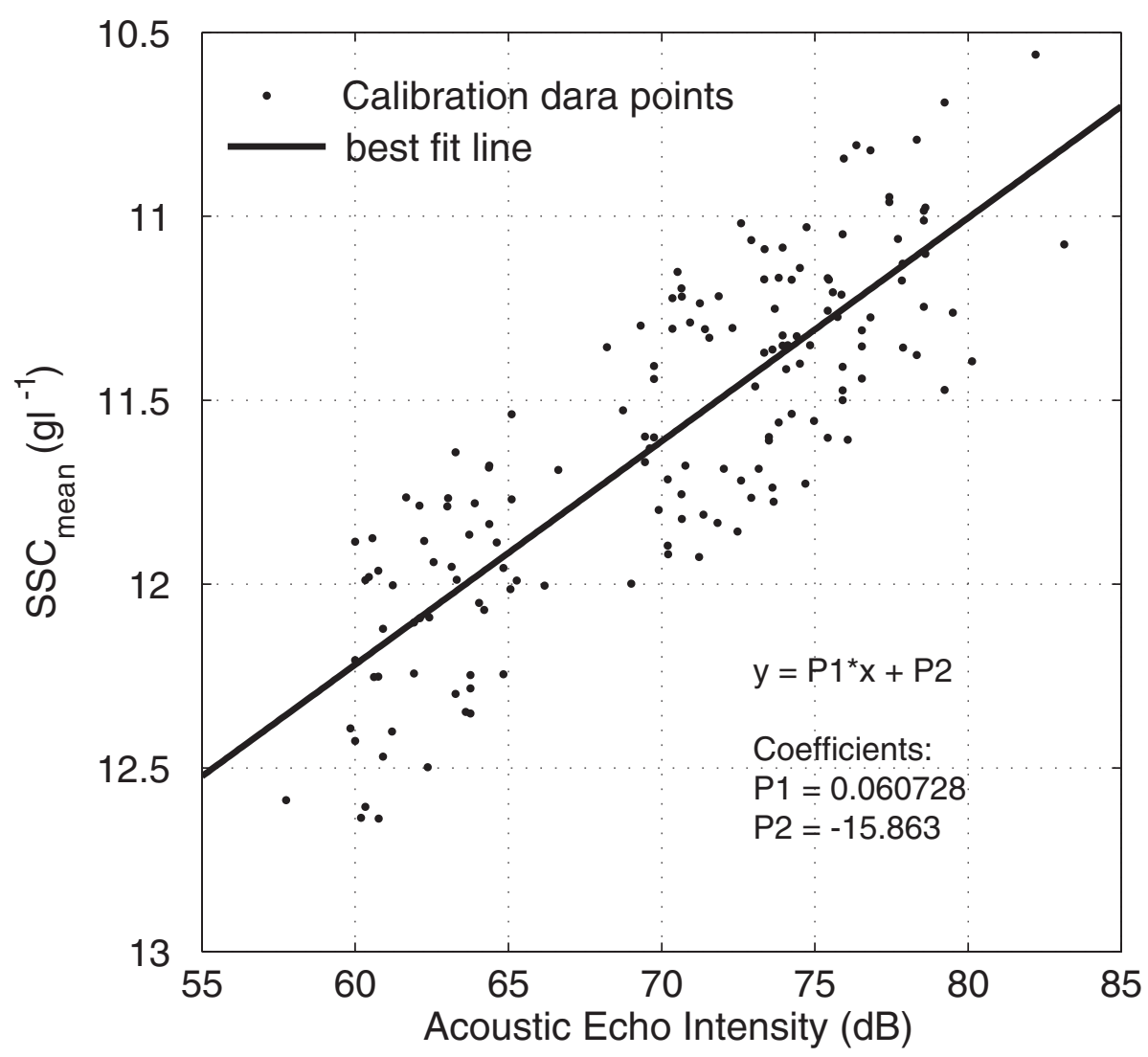

Fig. 2. Calibration of the ADCP backscatter intensity data using the direct sample concentrations. The direct sample concentrations were obtained in two $25 \mathrm{~h}$ periods during the spring tide and neap tide at station C3 (Fig. 1). Six samples were collected in each hour in vertical profiles aimed to quantify the vertical and temporal variation of the SSC across the water column. $A$ and $B$ values in regression respectively are $-15.863,0.060728$.
OSD

$8,1601-1630,2011$

Estimating SSC from ADCP backscatter

P. Ghaffari et al.

Title Page

\section{Abstract}

Introduction

Conclusions

References

Tables

Figures

14

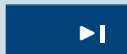

4

4

Back

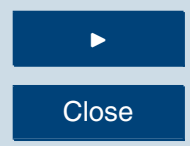

Full Screen / Esc

Printer-friendly Version

Interactive Discussion 


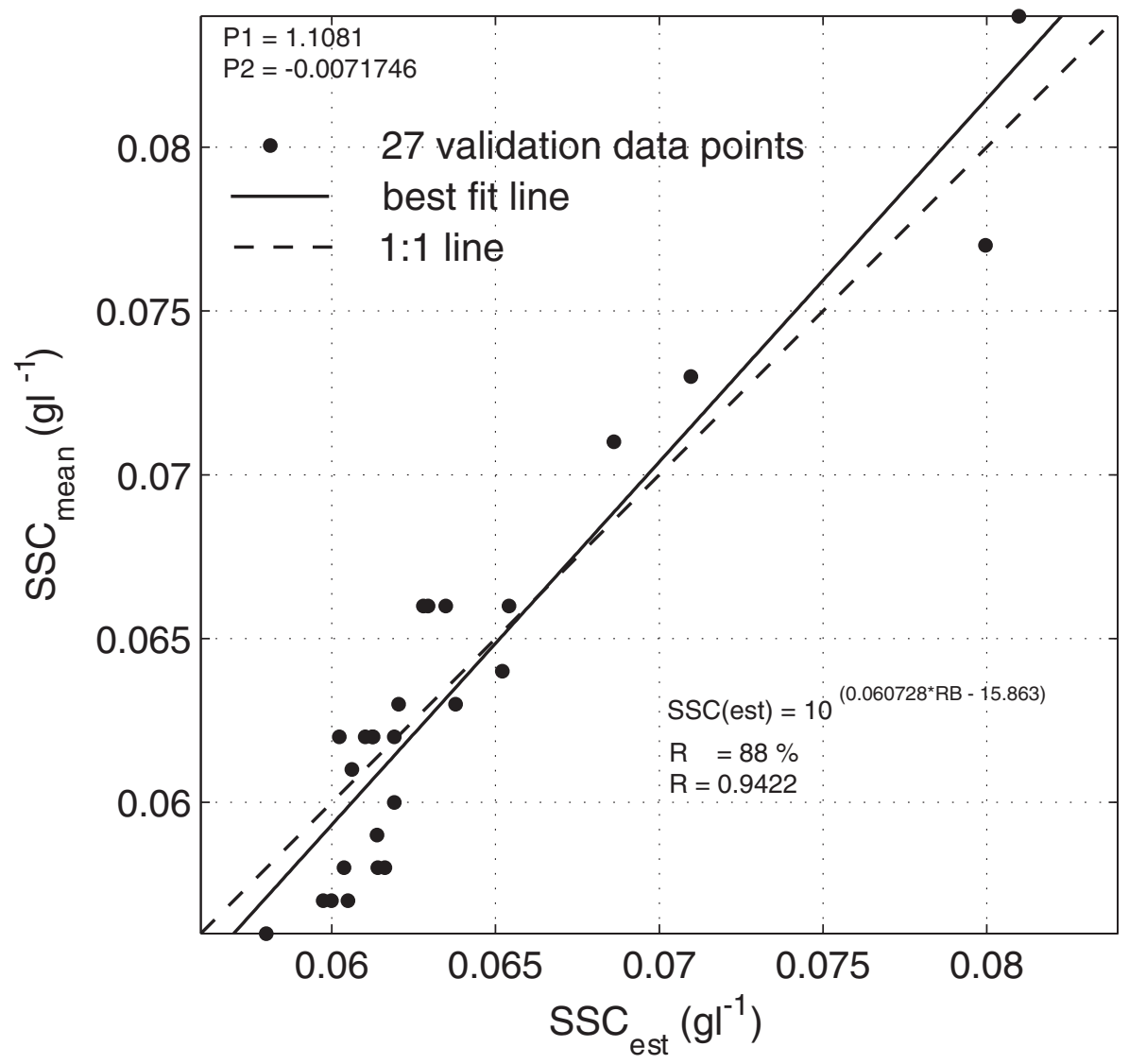

Fig. 3. Validation of the estimated SSC using the second group lab based conventional SSC data. Figure shows a rather high correlation between lab based and acoustic based particles in suspension $\left(R^{2}=88 \%\right)$. Concerning the $1: 1$ line with best-fit linear regression line, the ADCP-based SSC estimates are slightly underestimate.
OSD

$8,1601-1630,2011$

Estimating SSC from ADCP backscatter

P. Ghaffari et al.

Title Page

\section{Abstract}

Introduction

Conclusions

References

Tables

Figures
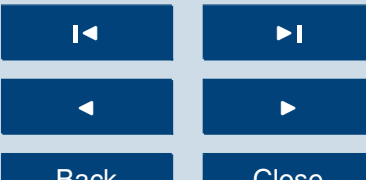

Back

Close

Full Screen / Esc

Printer-friendly Version

Interactive Discussion 


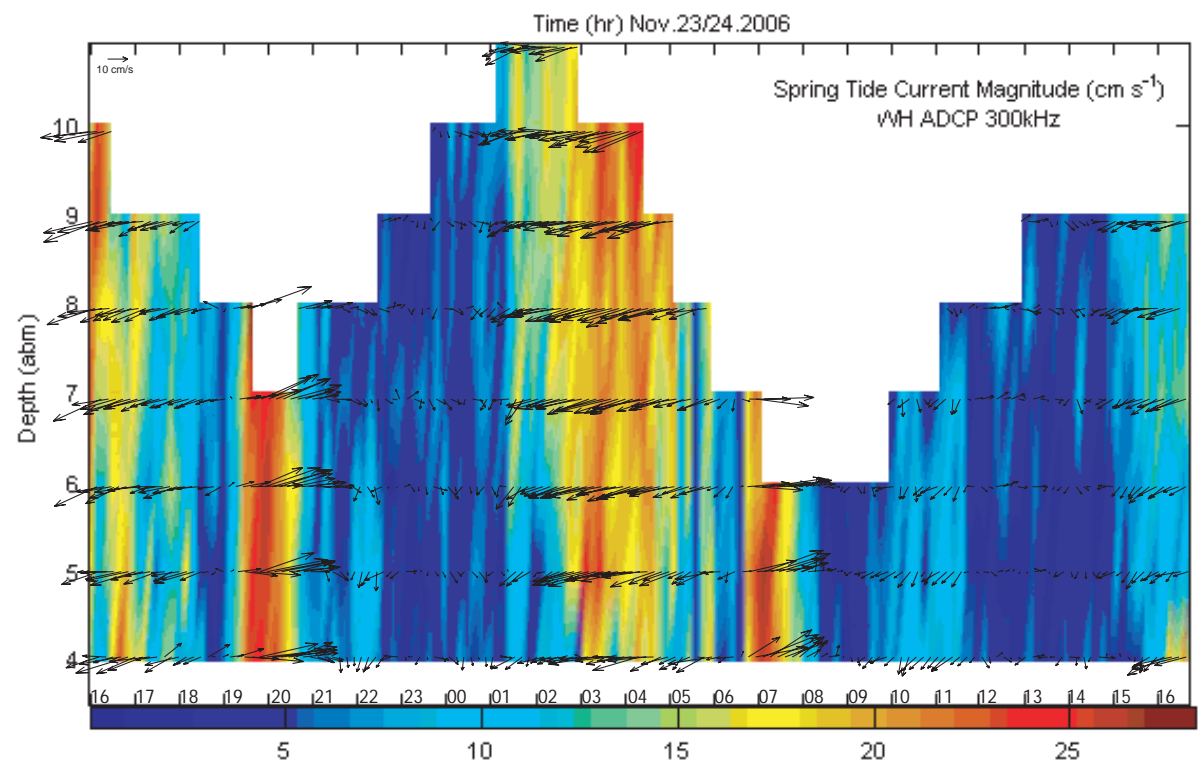

Fig. 4. Time series of $25 \mathrm{~h}$ data of tidal elevation, current speed and direction by ADCP during spring tide (from 16:00, 23 November to 17:00, 24 November 2006). Strong currents are more evident during the ebb periods.

\section{OSD}

$8,1601-1630,2011$

\section{Estimating SSC from ADCP backscatter}

P. Ghaffari et al.

Title Page

Abstract

Introduction

Conclusions

References

Tables

Figures

14

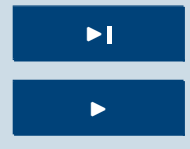

Back

Close

Full Screen / Esc

Printer-friendly Version

Interactive Discussion 
Time (hr) Nov 30,Dec 01.2006

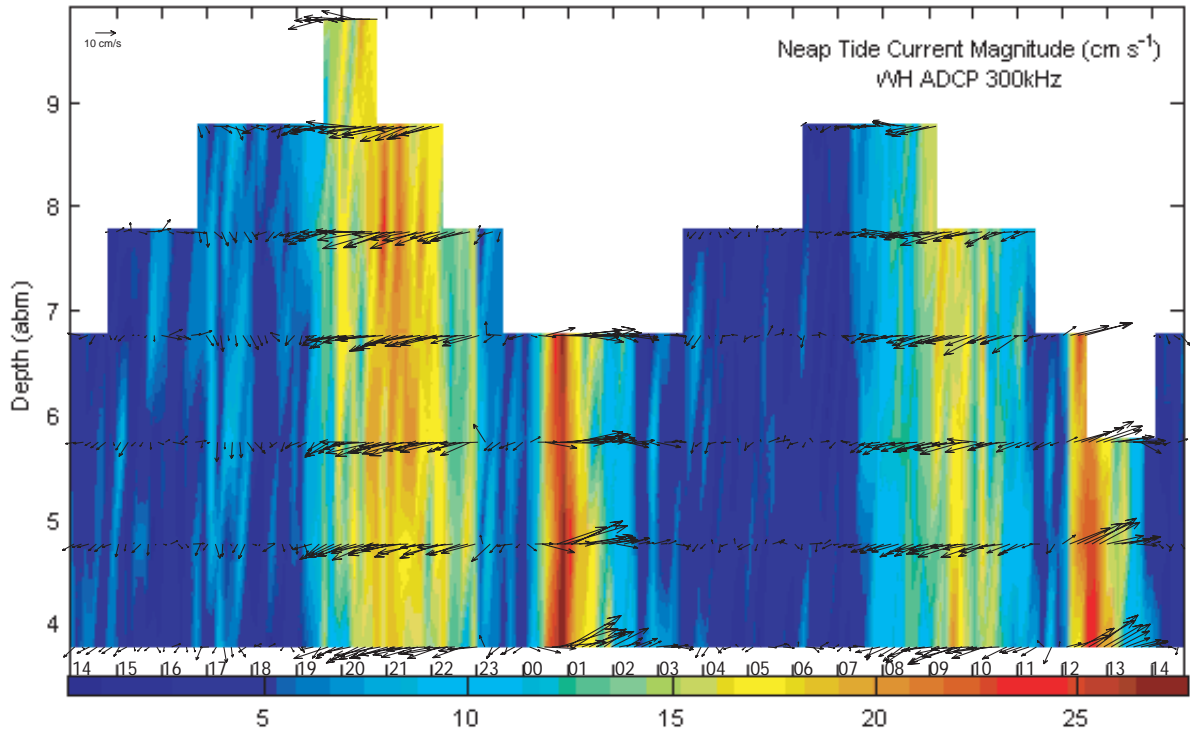

Fig. 5. Time series of $25 \mathrm{~h}$ data of tidal elevation, current speed and direction by ADCP during neap tide (from 14:00, 30 November to 15:00, 1 December 2006). Resemblance to spring tide, strong currents are more evident during the ebb periods.
OSD

$8,1601-1630,2011$

\section{Estimating SSC from ADCP backscatter}

P. Ghaffari et al.

Title Page

Abstract

Introduction

Conclusions

References

Tables

Figures

14

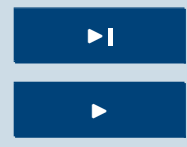

4

Back

Close

Full Screen / Esc

Printer-friendly Version

Interactive Discussion 


\section{OSD}

$8,1601-1630,2011$

\section{Estimating SSC from ADCP backscatter}

P. Ghaffari et al.

\section{Title Page}

\section{Abstract}

Introduction

Conclusions

References

Tables

Figures

Fig. 6. Left panel shows the mean zonal and meridional components of velocity in the MC. Thick and thin lines show zonal and meridional mean velocities and solid lines and dashed lines are representative for spring and neap tides respectively. Red and blue dashed (zonal components) and dot-dashed (meridional components)lines are depth average velocities over the whole recording periods for spring and neap tides respectively. In the right panels current ellipses are shown for spring and neap tides. Comparing the semi-major and semi-minor axes of ellipses it is evident that the flow field tends to be along channel. Two exemptions are the last bins in both spring and neap tides which happened due to low data quantity (approx. 12 velocity records were available).
14

4

Back

Full Screen / Esc

Printer-friendly Version

Interactive Discussion 


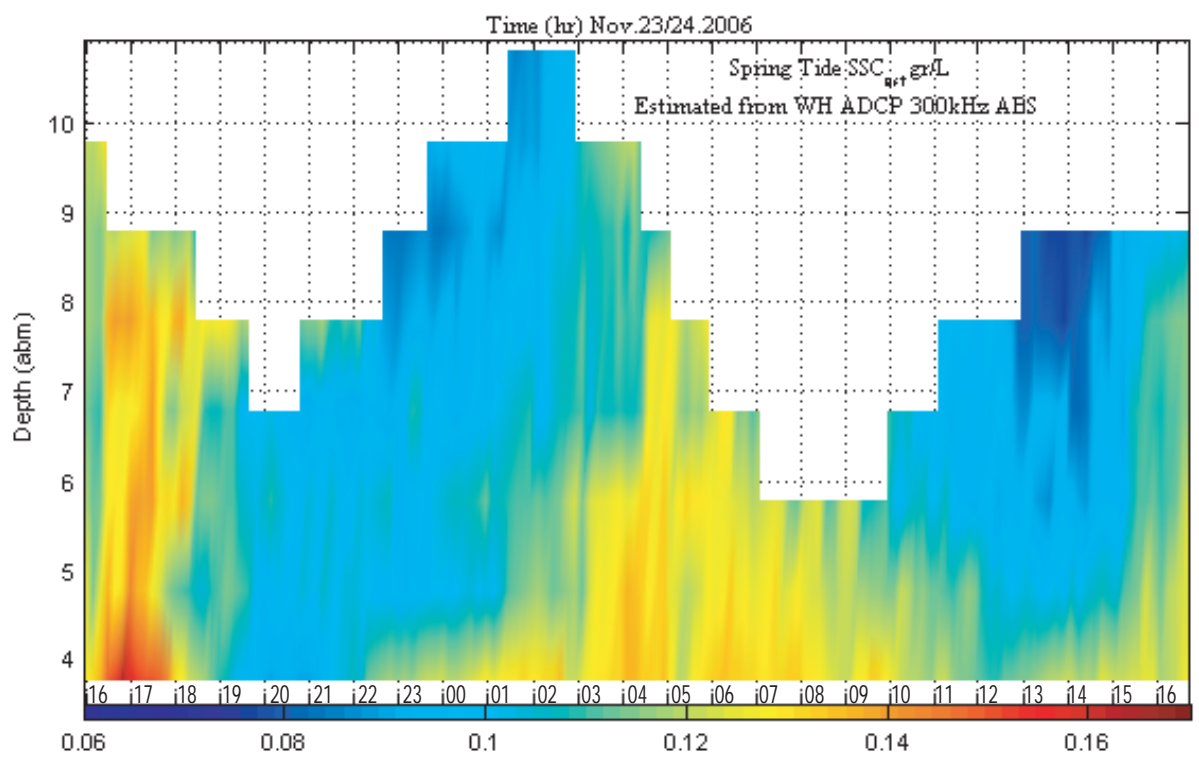

Fig. 7. Estimated suspended sediment concentrations during the spring tide in barge harbor off the MC. Higher concentrations are evidence in ebb periods and in bottom layers.
OSD

$8,1601-1630,2011$

\section{Estimating SSC from ADCP backscatter}

P. Ghaffari et al.

Title Page

Abstract

Introduction

Conclusions

References

Tables

Figures

14

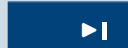

4

Back

$>$

Close

Full Screen / Esc

Printer-friendly Version

Interactive Discussion 


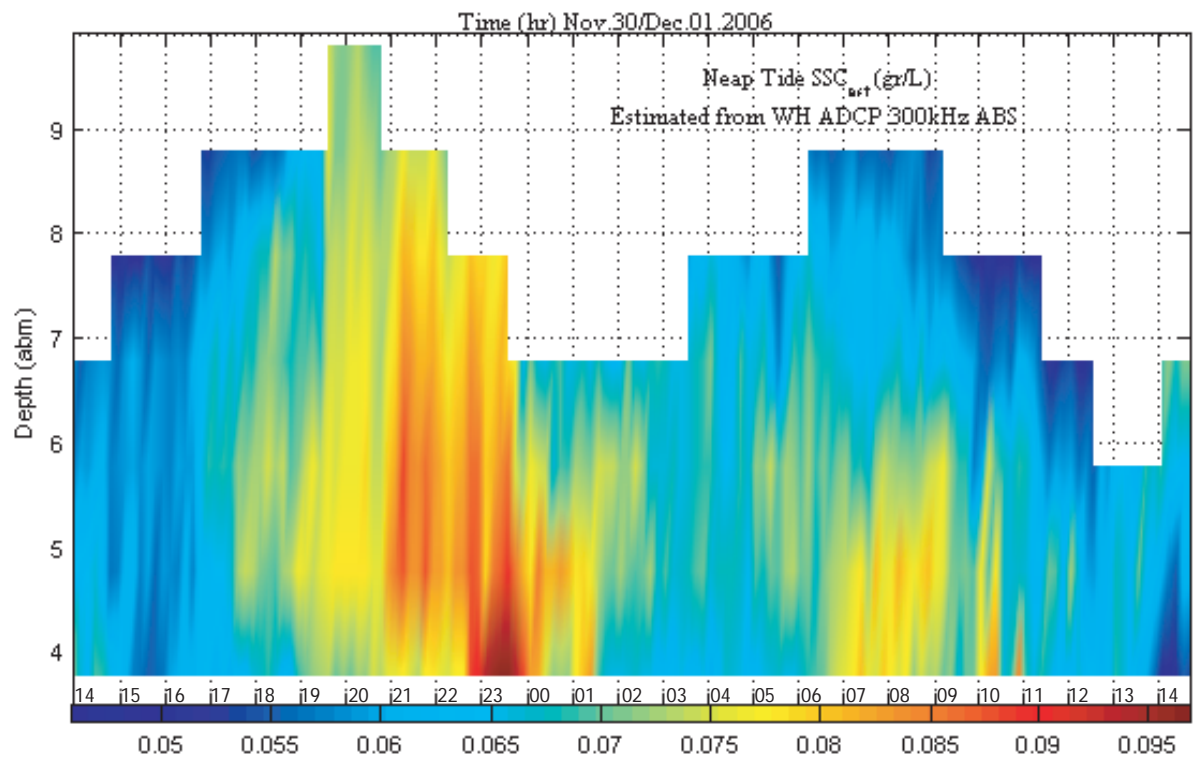

Fig. 8. Estimated suspended sediment concentrations during the neap tide in barge harbor off the MC. As expected from current time series, higher concentrations are evidence in ebb periods. SSC values are almost half comparing to the spring tide, shows almost half.
OSD

$8,1601-1630,2011$

\section{Estimating SSC from ADCP backscatter}

P. Ghaffari et al.

Title Page

Abstract

Introduction

Conclusions

References

Tables

Figures

14

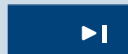

4

Back

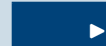

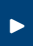

Close

Full Screen / Esc

Printer-friendly Version

Interactive Discussion 